\section{Commentary: The Ross procedure in adults: Getting better but proceed with caution}

\section{Leonard N. Girardi, MD}

In this issue of JTCVS Techniques, Starnes and his team ${ }^{1}$ have allowed all of us with an interest in aortic root disease a detailed look at how experienced surgeons perform the Ross procedure in young adults with aortic root disease, ascending aneurysms, and/or native aortic valve pathology. In addition to the outstanding narrative provided by the authors, the medical illustrator deserves applause for producing high-quality illustrations that provide readers with the visuals to inspire confidence that, with enough preparation and perhaps a little mentoring by an experienced Ross surgeon, one could perform this procedure themselves.

There are 2 important messages within this manuscript that are noteworthy. First, with meticulous surgical technique, great outcomes can be achieved even when performing highly complex cardiovascular operations. The operative mortality for 129 young patients (median age 35 years) undergoing a Ross procedure for bicuspid aortic valve disease was $1.6 \%(2 / 129)$. The need for re-exploration for postoperative hemorrhage was also very low $(7 / 129,5.4 \%)$, whereas the incidence of significant heart block requiring a permanent pacemaker was less than $2 \%(2 / 129,1.6 \%)$. Obviously, the senior author's decades of experience with the Ross procedure are a major contributor to such admirable results.

Second, the improvement in long-term outcome is directly attributed to the technique of wrapping the autograft with Dacron. When calculating the cumulative incidence of pulmonary autograft reintervention with death as a competing risk, the presence of a "wrapped" autograft

From the Department of Cardiothoracic Surgery, Weill Cornell Medicine, New York, NY.

Disclosures: The author reported no conflicts of interest.

The Journal policy requires editors and reviewers to disclose conflicts of interest and to decline handling or reviewing manuscripts for which they may have a conflict of interest. The editors and reviewers of this article have no conflicts of interest.

Received for publication Aug 19, 2021; revisions received Aug 19, 2021; accepted for publication Aug 20, 2021; available ahead of print Aug 26, 2021.

Address for reprints: Leonard N. Girardi, MD, Department of Cardiothoracic Surgery,

Weill Cornell Medicine, New York, NY 10021 (E-mail: lngirard@med.cornell. edu).

JTCVS Techniques 2021;10:379-80

2666-2507

Copyright (C) 2021 The Author(s). Published by Elsevier Inc. on behalf of The American Association for Thoracic Surgery. This is an open access article under the CC BY-NC-ND license (http://creativecommons.org/licenses/by-nc-nd/4.0/).

https://doi.org/10.1016/j.xjtc.2021.08.034

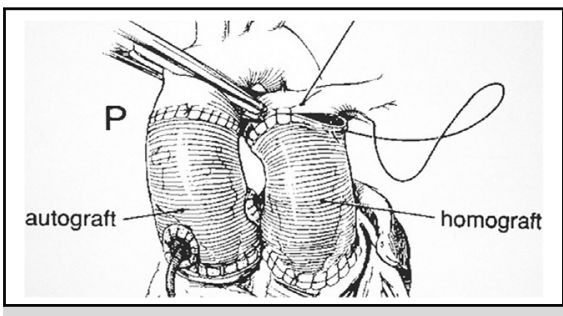

Ross procedure with pulmonary autograft in the aortic position and pulmonic homograft.

CENTRAL MESSAGE

The Ross procedure is a complex cardiac operation. Operative outcomes are excellent in experienced hands, and long-term durability has improved with the addition of external support.

was highly protective against reintervention $(P=.023$, SHR, 0.38; confidence interval, 0.08-0.91). ${ }^{2}$ The cumulative incidence of autograft reintervention in the "wrapped" cohort was a consistent $4 \%, 4 \%$, and $4 \%$ at 1,5 , and 10 years, respectively, whereas those undergoing an unwrapped Ross had a cumulative incidence of $10.2 \%$, $14.9 \%$, and $26.8 \%$ over the same time interval. Pulmonary autograft support is crucial for long-term success, as others have demonstrated similar long-term durability of the Ross when using the native aortic root as external support. ${ }^{3}$ Comparing modes of late autograft failure between these techniques lends further support to the need for external scaffolding. When the Ross is wrapped, a majority of the late reoperations were for isolate leaflet failure. None were for autograft root dilatation, whereas those having an unwrapped Ross required a full root replacement $64 \%$ of the time. ${ }^{1}$ Stable aortic root dimensions at 5, 10, and 15 years (34.0, 34.6, and $34.7 \mathrm{~mm}$, respectively) after a Ross further reaffirms the durability of the Ross when performed with some form of external support of the pulmonary autograft. ${ }^{3}$

The senior author's decades of experience obviously make a significant contribution to the outcomes published within this treatise. However, his commitment to teaching the procedure is self-evident with this publication (and through his development of young faculty who now also comfortably perform the Ross). With a sound commitment to properly learning this procedure, and the use of external support of the pulmonary autograft, more widespread application of this surgical tour-de-force is possible. 


\section{References}

1. Starnes VA, Bowdish ME, Cohen RG, Baker CJ, Elsayed MD. The Ross procedure utilizing the pulmonary autograft inclusion technique in adults. J Thorac Cardiovasc Surg Tech. 2021;10:372-6.

2. Starnes VA, Elsayed RS, Cohen RG, Olds AP, Bojko MM, Mack WJ, et al. Longterm outcomes with the pulmonary autograft inclusion technique in adults with bicuspid aortic valves undergoing the Ross procedure. J Thorac Cardiovasc Surg. February 4, 2021 [Epub ahead of print].

3. Skillington PD, Mokhles MM, Takkenberg JJ, Larobina M, O'Keefe M, Wynne R, et al. The Ross procedure using autologous support of the pulmonary autograft: techniques and late results. J Thorac Cardiovasc Surg. 2015; 149(2 suppl):S46-52. 